\title{
The analysis of validity and reliability of self- regulated learning scale
}

\author{
Said Alhadi, W. N. E.Saputra\&A.Supriyanto \\ Faculty of Education: dept. ... \\ Universitas Ahmad Dahlan \\ Yogyakarta, Indonesia \\ said.alhadi@bk.uad.ac.id
}

\begin{abstract}
Self-regulated learning is one of the ability of individuals to manage themselves, especially in learning. Therefore, it is necessary to develop self-regulated learning scale that can measure the level of self-regulated learning of students. The self-regulated learning scale before being used needs to be tested to determine the validity and reliability. This study used product moment correlation to determine the level of validity and alpha cronbach formula to determine the level of reliability. The validity and reliability of self-regulated learning scale were tested using SPSS 16 applications. 43 items of which are valid with the reliability coefficient of 0.880 included in the category of high reliability. Based on the results of validity and reliability analysis, the scale of self-regulated learning is ready to be used to measure the level of students' self-regulated learning
\end{abstract}

Keywords—validity and reliability; self-regulated learning scale

\section{INTRODUCTION}

The government is developing the quality of education as an attempt to support the quality of human resources. It is in accordance with the preamble of 1945 Constitution stating that one of the aims of the Republic of Indonesia is to improve the public welfare and to educate the life of the people. Quality improvement of human resources requires improvement in the education field [20]. One of the examples is by increasing the standardization of the final score of the students' every year through the government policies. To anticipate the anxiety about learning outcomes, the readiness of all components cannot be avoided. One of them is self-regulated learning. In addition, self-regulated learning is one of the competences that should be acquired by students in the 21 st century [7;24]. In the research by [4], it is mentioned that self-regulated learning can be one of the factors improving students learning outcome in junior high schools in Yogyakarta.

Counselors play significant role in improving students' self-regulated learning. Counselors have many competences that can be applied in the effort to identify and to improve the level of students' self-regulated learning. Counselors need to know the level of the students' self-regulated learning which is one of the factors determining students' learning outcomes. It is conducted to help counselors to design certain program in guidance and counseling to improve students' self-regulated learning.

Self-regulated learning is a learning situation where students have control over the learning process through their knowledge and suitable learning strategies, understanding their duties, encouragement in decision making, and learning motivation [9]. Further, [21] proposed that self-regulated learning is a concept on how a student regulates his own learning process.

Self-regulated learning emphasizes on an individual's ability to be disciplined and to control themselves, especially when they are having difficult tasks. Besides, self-regulated learning highlights initiative for it comes from within an individual's initiative to learn. Students with initiative show their ability to use their ideas, feelings, strategies, and behaviors to achieve their goals [25].

Several researches showed that self-regulated learning influenced students' learning outcomes. The research by [27] found that students who can use their strategies in selfregulated learning achieve better outcomes compared to those who do not. The research by [15] found that self-regulated learning influenced students' achievement. [14] concluded that self-regulated learning was significantly correlated with learning outcomes. The research conducted by [17] showed that self-regulation strategies influenced students' learning outcomes in mathematics.

Self-regulated learning is a conscious attempt of the students to regulate things related to their independent learning. The success of their learning can be achieved through self-regulation in proper learning. The better the students regulate themselves, the closer they are to success. High achiever students are defined as self-regulated learners [19]. According to [23], students' self-regulated learning includes the ability to set their own score target, to plan their schedules, to manage their time of playing and studying, and to prepare themselves for daily tests. All of them lead them to 
improve their achievements at school. One of the services in guidance and counseling, which is informa-tion service, can be implemented in improving students' achievement in selfregulated learning [1].

This research aims to formulate an instrument to measure students' self-regulated learning. Before it is ready, an instrument needs to be tested in order to determine its level of validity and reliability. The tested instrument can be used by counselors to identify students' self-regulated learning as well as the cause of students' lack of self-regulated learning. Thus, counselors can develop certain strategies to help students achieve their academic success.

\section{METHOD}

This research sought to develop an instrument to measure the level of self-regulated learning of students, namely the self-regulated learning scale. Before an instrument is used, it needs to be tested. This research was aimed to determine the validity and reliability of self-regulated learning scale. In this study, instrument testing was imposed on 125 students. Product moment correlation was used to analyze the validity. While reliability level of the instrument was measured using alpha cronbach formula.

\section{RESULTS AND DISCUSSION}

The validity and reliability of self-regulated learning scale were tested using SPSS 16 applications. 43 items of which were valid with the reliability coefficient of 0.880 included in the category of high reliability. Based on the analysis results of validity and reliability, the scale of self-regulated learning is ready to be used to measure the level of self-regulated learning of students.

The instrument of self-regulated learning scale was developed from two aspects. First, students systematically lead themselves to understand the learning materials. Second, students systematically lead themselves to regulate their attitude towards learning. These two aspects are the key factors in developing the instruments to measure students' self-regulated learning ability.

The development of self-regulated learning instrument is used in the purpose of identifying the students' ability in regulating themselves to learn. The results of the identification become the guidelines for the counselors to design particular program that will be useful to improve students' self-regulated learning. It helps students to improve their academic success.

The concept of self-regulated learning is becoming increasingly relevant in learning and academic achievement in which quite distinctive demands are placed on students [6]. Self-regulated learning is a combination of academic learning skills and self control that ease the learning process leading the students to be more motivated [10]. Self-regulated learning contains skills and willingness to learn. Students with selfregulated learning transform their mental abilities into academic skills and strategies [25].

One of the roles of counselor is to promote self- regulated learning to students. Referring to the research by [13], it showed that many teachers have not encouraged self-regulated learning to students. It resulted in decreasing academic achievements of the students.

Various researches showed that students' self-regulated learning influences their academic achievement. It was shown in the research by [5]. Students with high self-regulated learning tend to achieve higher in the academic performance. Conversely, students with low self-regulated learning tend to achieve lower. The research was supported by [16], concluding that the level of students' self-regulation influence their academic success. Another research, conducted by [3], stated that there was negative and significant correlation between academic procrastination and self-regulated learning of the students in SMA Negeri 1 Samarinda. It means that the higher the academic procrastination is, the lower the students' self-regulated learning is. In fact, this low academic procrastination will lower the students' learning achievement [2].

There are several factors encouraging students' self regulation. [26] stated that one factor of self-regulated learning is motivation. Individuals who are highly motivated to learn will manage themselves to learn well. Besides, other research conducted by [12] explained that meta-cognition is one of the causes of self-regulated learning and academic success. The research was supported by [8] claiming that meta-cognition interacts with motivation and initiates students' self-regulated learning.

Students' self-regulated learning needs to be improved. The purpose is to make the students more independent in managing their own time to learn and in achieving their academic success. According to [11], self-regulated learning of junior high students can be improved through guidance and counseling services, especially through Online Cognitive Behavioral Counseling Model. Besides, according to [18] teachers can also develop their self-regulated learning by optimizing proportional assignments for the students. While accomplishing the tasks, students have more time to manage themselves through self-motivation, anticipation of disturbance, particular strategies to finish their homework, self-management, goal setting, self-reflection on their performance, and deferring gratification. Other research by [22] stated that self-regulated learning can be improved through inquiry based learning.

The establishment of self-regulated learning scale is expected to help counselor in schools to identify students' self-regulated learning level. The identification can be the guidelines for counselors to design particular strategies to develop students' self-regulated learning leading the students to be more independent in arranging their learning schedules, choosing more useful activities, and motivating themselves to learn. Besides, the identification supports the students' goal at school, which is to achieve academic success.

\section{CONCLUSION}

Self-regulated learning is a situation where students have control over the learning process through their knowledge and suitable strategies, their understanding on their tasks, encouragement in decision making, and learning motivation. The ability of self-regulated learning needs to be identified 
using self-regulated learning scale. The trial result of the selfregulated learning scale to test the validity and reliability showed high category. Valid and high reliability coefficient instruments are supposed to be used by the counselors to identify students' self-regulated learning. By doing so, counselors can design a program to improve the self-regulated learning to support their academic career.

\section{REFERENCES}

[1] Adiningtyas, S.W. 2016. Pelaksanaanlayananinformasidengan movie maker dalammeningkatkan self-regulated learn-ing. Kopasta, 3(1): 9-13.

[2] Akinsola, M.K., Tella, A. and Tella, A. 2007. Correlates of academic procrastination and mathematics achievement of university undergraduate students. Eurasia Journal of Mathematics, Science \& Technology Education, 3(4): 363-370.

[3] Alfina, I., 2014. Hubungan self-regulated learning denganprokrastinasiakademikpadasiswaakselera-si. JurnalPsikologi, 2(2): 227-237.

[4] Alhadi, S. 2016. Self-regulated learning to increase learning re-sult for students of junior high school. In Proceeding of 2nd International Conference on Education and Training (2nd ICET): Quality Improvement in Education and Training - Theory and Practices, Malang Indonesia, 7 November 2015.

[5] Barnard-Brak, L., Paton, V.O. and Lan, W.Y. 2010. Profiles in selfregulated learning in the online learning environ-ment. The International Review of Research in Open and Distributed Learning, 11(1): 61-80.

[6] Cassidy, S. 2011. Self-regulated learning in higher education: Identifying key component processes. Studies in Higher Education, 36(8): 989-1000.

[7] Collins, J. 2009. Lifelong learning in the 21st century and beyond. Radiographics, 29(2): 613-622.

[8] Efklides, A. 2011. Interactions of metacognition with motiva-tion and affect in self-regulated learning: The MASRL model. Educational psychologist, 46(1): 6-25.

[9] Ellianawati, E. and Wahyuni, S. 2016. Pemanfaatan model self-regulated learning sebagaiupayapeningkatankemampuanbelajarmandiripadamatakuliahoptik. JurnalPendidikanFisika Indonesia, 6(1): 35-39.

[10] Glynn, S.M., Aultman, L.P. and Owens, A.M. 2005. Motivation to learn in general education programs. The Journal of General Education, 54(2): 150-170.

[11] Hidayah, N. 2013. Online cognitive behavioral counseling model to improve junior high school students' self-regulated learning. In THE INTERNATIONAL CONFE-RENCE, p. 52.

[12] Isaacson, R. and Fujita, F. 2012. Metacognitive knowledge monitoring and self-regulated learning. Journal of the Scholarship of Teaching and Learning, 6(1): 39-55
[13] Kistner, S., Rakoczy, K., Otto, B., Dignath-van Ewijk, C., Büttner, G. and Klieme, E. 2010. Promotion of self-regulated learning in classrooms: Investigating frequency, quality, and consequences for student perfor-mance. Metacognition and Learning, 5(2): 157-171.

[14] Kosnin, A.M. 2007. Self-regulated learning and academic achievement in Malaysian undergraduates. International Education Journal, 8(1): 221 228

[15] Latipah, E. 2010. Strategi self-regulated learning danprestasibelajar: Kajian meta analisis. JurnalPsikologi, 37(1): 110-129.

[16] Mega, C., Ronconi, L. and De Beni, R., 2014. What makes a good student? How emotions, self-regulated learning, and motivation contribute to academic achievement. Journal of Educational Psychology, 106(1): 121

[17] Mousoulides, N. and Philippou, G. 2005. Students' motivation-al beliefs, self-regulation strategies and mathematics achievement. In Proceedings of the 29th Conference of the International Group for the Psychology of Mathematics Education 3: 321-328. PME

[18] Ramdass, D. and Zimmerman, B.J. 2011. Developing self-regulation skills: The important role of homework. Journal of advanced academics, 22(2): 194-218.

[19] Santrock, J. W. 2008. PsikologiPendidikan. Jakarta: Kencana-Prenada Media.

[20] Sardjoko, S. 2015. Pembangunan pendidikan dalam RPJMN 2015-2019 (Perpres No. 2 Tahun 2015). Jakarta: Deputi Menteri Bidang Pembangunan, Masyarakat, dan kebudayaan.

[21] Schunk, D. H., \& Zimmerman, B. J. 2012. Motivation and self-regulated learning: Theory, research, and applications. Routledge.

[22] Setyawati, S. P. 2015. Keefektifan model pembelajaran inquiry based learning untukmeningkatkan self directed learning mahasiswa. In Prosiding Seminar NasionalPendidikanEkonomi FE UNY: ProfesionalismePendidikdalamDinamika-KurikulumPendidikan di Indonesia pada Era MEA. Fakul-tasEkonomi UNY.

[23] Susanto, H. 2006. Mengembangkankemampuan self regulation untukmeningkatkankeberhasilanakademiksis-wa. JurnalPendidikanPenabur, 7: 64-71.

[24] Wolters, C.A. 2010. Self-regulated learning and the 21st cen-tury competencies. Universidad de Houston: Department of Educational Psychology. Consultado en: http://www. hewlett. org/uploads/Self_Regulated_Learning__21st_Century_Competencies. pdf.

[25] Zimmerman, B. J. 2002. Becoming a self-regulated learner: An overview. Theory into Practice, 41: 64-70.

[26] Zimmerman, B. J. 2011. Motivational sources and outcomes of selfregulated learning and performance. Dalam Zimmerman, B. J., \&Schunk, D. H. (Ed), Handbook of self-regulation of learning and performance: 49-64. New York: Springer Publishing Company

[27] Zuffianò, A., Alessandri, G., Gerbino, M., Kanacri, B.P.L., In-Giunta, L., Milioni, M. and Caprara, G.V. 2013. Academic achievement: The unique contribution of self-efficacy be-liefs in self-regulated learning beyond intelligence, perso-nality traits, and self-esteem. Learning and Individual Dif-ferences, 23: 158-162. 